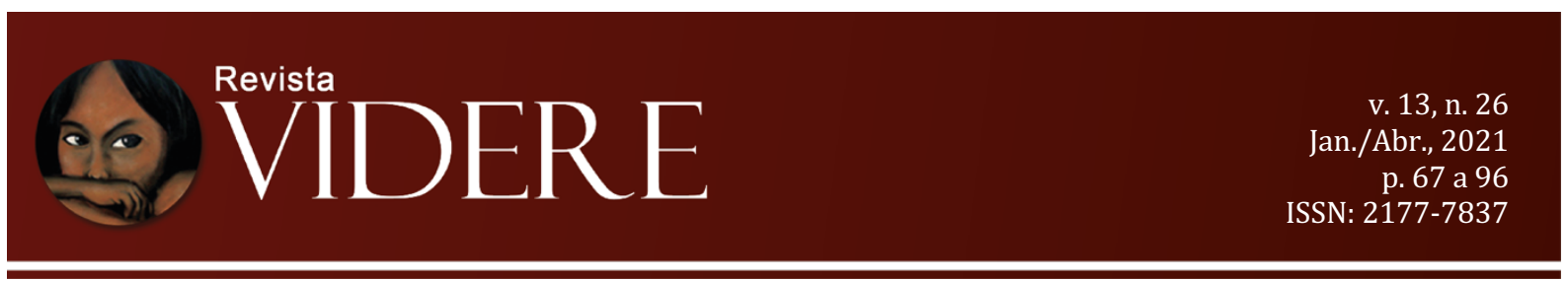

\title{
PROTAGONISMO FEMININO NO PROCESSO DE RECONHECIMENTO E TITULAÇÃO DA COMUNIDADE QUILOMBOLA KALUNGA
}

\author{
FEMALE PROTAGONISM IN THE KALUNGA QUILOMBOLA COMMUNITY \\ RECOGNITION AND TITLE PROCESS
}

\author{
PROTAGONISMO FEMENINO EN EL PROCESO DE RECONOCIMIENTO Y TÍTULO \\ COMUNITARIO DE KALUNGA QUILOMBOLA
}

Izadora Nogueira dos Santos Muniz

Doutoranda em Direito

Universidade de Brasília (UnB)

E-mail: n.izadora@gmail.com

OrcidID: https://orcid.org/0000-0002-2530-3441

José do Carmo Alves Siqueira

Prof. Dr. do Curso de Direito e do PPGDA

Universidade Federal de Goiás (UFG)

E-mail: josedocarmoas@gmail.com

OrcidID: https://orcid.org/0000-0002-6250-5288

Resumo: O artigo teve como objetivo abordar as experiências e trajetórias femininas como protagonistas pela efetivação dos constitucionais direitos territoriais da Comunidade Quilombola Kalunga. Sob uma perspectiva metodológica histórica, partindo de entrevistas semiestruturadas e com apoio nos referenciais teóricos de Anibal Quijano, Rita Segato e Clóvis Moura, o trabalho foca no processo de reconhecimento e titulação do quilombo, situado no Estado de Goiás, que se projeta internacionalmente. Infere-se, a partir desta pesquisa, que debater a estrutura fundiária, ou seja, a maneira como a propriedade da terra rural se distribui em determinado espaço geográfico, a partir do reconhecimento dos direitos territoriais das populações tradicionais, é debater, também, o uso sustentável dos recursos naturais, evidenciando as complexas experiências histórico-jurídicas do direito agrário, atravessado a todo momento pelos debates sobre igualdade étnico-racial e de gênero no Brasil.

Palavras-chave: Direito Agrário. kalungas. mulheres. terra e territorialidade. sujeitos de direitos coletivos.

Abstract: The article had as objective approach women's experiences and trajectories as protagonists for the realization of constitutional territorial rights of the Quilombola Kalunga 
Community. From a historical methodological perspective, starting from semi-structured interviews and supported by the theoretical references of Anibal Quijano, Rita Segato and Clóvis Moura, the study focuses on the process of recognition and titling of the quilombo, located in the state of Goiás, which is projected internationally. It is inferred from the research to debate the land structure, in other words, the way that rural land ownership is distributed in a given geographical space, based on the recognition of the territorial rights of traditional populations, is also to debate the sustainable use of natural resources, showing, the complex historical-juridical experiences of agrarian law, crossed at all times by debates on ethnic-racial and gender equality in Brazil.

Keywords: Agrarian Law. kalungas. women. Land and territoriality. collective rights subjects.

Resumen: El artículo tuvo como objetivo abordar las experiencias y trayectorias de las mujeres como protagonistas para la implementación de los derechos territoriales constitucionales de la Comunidad Quilombola Kalunga. Desde una perspectiva metodológica histórica, a partir de entrevistas semiestructuradas y sustentadas en los marcos teóricos de Anibal Quijano, Rita Segato y Clóvis Moura, el trabajo se centra en el proceso de reconocimiento y titulación del quilombo, ubicado en el Estado de Goiás, que se proyecta internacionalmente. De la investigación se infiere que debatir la estructura de la tierra, es decir, la forma en que se distribuye la propiedad rural en un espacio geográfico dado, a partir del reconocimiento de los derechos territoriales de las poblaciones tradicionales, es también debatir el uso sostenible de los recursos naturales, evidenciando las complejas experiencias histórico-legales del derecho agrario, atravesadas en todo momento por debates sobre la igualdad étnico-racial y de género en Brasil.

Palabras clave: Derecho Agrario. kalungas. mujeres. tierra y territorialidad. sujetos de derechos colectivos.

\section{Introdução}

Situada nos municípios de Cavalcante, Monte Alegre e Teresina de Goiás, e reconhecida pelo Governo do Estado de Goiás, desde 1991, como Sítio Histórico que abriga o Patrimônio Cultural Kalunga, maior quilombo em extensão territorial do Brasil ${ }^{1}$, a comunidade encontra-se em processo de regularização no Instituto Nacional de Colonização e Reforma Agrária (INCRA), desde 2004, aguardando o decreto Presidencial de desapropriação por interesse social. Essa morosidade reflete o tratamento civilista e patrimonialista da terra, por parte de instituições estatais, e expõe a continuação dos obstáculos para o aprofundamento da cidadania coletiva afirmada na Constituição brasileira de 1988.

\footnotetext{
${ }^{1}$ Atualmente, o território quilombola em Oriximiná, no Estado do Pará, reivindica o título de maior quilombo em extensão territorial do Brasil, o que faria com que a Comunidade Kalunga ocupasse a segunda posição.
} 
Nesse contexto, a fim de confrontar a perspectiva da propriedade clássica, o presente trabalho parte da análise da atuação das mulheres quilombolas Kalungas, enquanto sujeitos constitucionais de direitos, na luta pela efetivação do artigo 68 do Ato das Disposições Constitucionais Transitórias (ADCT) da Constituição da República Federativa do Brasil de 1988 (CRFB/88). Buscamos, assim, compreender qual é a participação das mulheres Kalungas no reconhecimento e titulação, ainda que parcial, da terra dessa comunidade quilombola.

\section{Resistência quilombola ao modelo de produção escravista e patriarcal}

É importante compreender que só existem quilombos no Brasil porque houve um processo colonial e porque houve escravidão. De acordo com Quijano (2005), essa forma de dominação e exploração só foi possível mediante a codificação das diferenças entre conquistadores e conquistados na ideia de raça, isto é:

(...) uma supostamente distinta estrutura biológica que situava a uns em situação natural de inferioridade em relação a outros. Essa ideia foi assumida pelos conquistadores como o principal elemento constitutivo, fundacional, das relações de dominação que a conquista exigia. Nessas bases, consequentemente, foi classificada a população da América, e mais tarde do mundo, nesse novo padrão de poder (QUIJANO, 2005, p. 117).

Foi através do tráfico atlântico que diferentes povos e etnias eram desembarcados no Brasil: "de origens múltiplas, todos eles foram transformados - na visão dos europeus - em africanos, como se houvesse homogeneidade para inúmeros povos, línguas, culturas e religiões" (GOMES, 2015, p. 7). Induzidos pelos compradores das Américas, esse tráfico gerou uma desproporção imensa entre homens e mulheres no Brasil: "Fato constatado indiscutível é o da predominância do sexo masculino nas cargas dos navios negreiros. Em regra, traziam da África duas ou três vezes mais homens do que mulheres" (GORENDER, 2016, p. 79).

Estimativas da historiadora Schwarcz (2018) e de Gorender (2016) sinalizam um desequilíbrio na composição sexual, na ordem de $70 \%$ (setenta por cento) de homens para 30\% (trinta por cento) de mulheres. Gorender (2016) apura que tal desproporção se dava por conta do fator "demanda", uma vez que o sistema econômico da plantagem escravista, nos engenhos de açúcar, deu preferência ao trabalhador masculino (em que pese a agricultura, que até meados do século XIX, não ser de larga escala e de exportação naquele continente e, em alguns casos, a mineração, na África, ser ocupação costumeiramente de mulheres). O historiador acaba indagando, diante das disparidades nas proporções, se os plantadores acertavam nessa 
preferência masculina, do ponto de vista da eficiência econômica, ou se faziam somente um julgamento próprio da tradição cultural europeia.

Por conta da preferência masculina na demanda do tráfico negreiro, uma ameaça se intensificava sobre as mulheres escravizadas, porque, em menor número, viviam cercadas de grande número de escravizados homens. E, ainda, as mulheres eram violentadas por proprietários brancos, seus filhos e feitores: "Do assédio dos homens brancos às escravas diz bem o fato de que, já em 1836, os escravos de cor parda, em número de 14.722, representavam 16,9\% do total servil da província de São Paulo" (GORENDER, 2016, p. 65).

Assim, a estimativa demográfica, apresentada por Gorender (2016) e Schwarcz (2018), indica vinculação entre escravidão, cultura da força e estupro. Da mesma forma, autores como Moura (1981), Gorender (2016), Gomes (2015), Souza Filho (2017) e Fiabani (2005) apresentam elementos da relação entre o escravismo colonial, voltado para a produção comercial de exportação, como forma de viabilizar o modelo de exploração de grandes extensões de terra (latifúndios) e uma prática de degradação da natureza.

A escravidão colonial foi a forma encontrada pelos europeus para expropriar a natureza, permitindo a acumulação primitiva, na fase anterior do capital. Gorender (2016) avalia que a estrutura profunda do modo de produção hegemônico na pré-abolição - que só se deu em 1888, no Brasil - constitui a gênese da produção capitalista. Em outras palavras, a escravidão colonial estruturou a matriz econômica e patriarcal de dominação: “(...) o cultivo da terra, voltado para o mercado externo, exigia grandes somas para a compra de escravos e ferramentas, e só a exploração de vastas extensões era lucrativa" (JAHNEL, 1987, apud FIABANI, 2005, p. 352).

Nesse quadro, a exploração do homem negro e da mulher africana escravizada foi sempre acompanhada de constantes atos de rebeldias que se faziam sentir no cotidiano, desde a resistência à escravização como "corpo mole", desídia para o trabalho, tentativas de assassinato de feitores e senhores, até suicídios. Além do mais, a audácia expressa da reação à opressão adotou as fugas como atos de resistência. Para Clóvis Moura (1981), é no abandono do trabalho que a pessoa escravizada dinamizava, por negação, o sistema e se afirmava como sujeito histórico coletivo. Assim, muitos negros e negras que fugiam e não eram recapturados acabavam organizando comunidades negras livres, originando quilombos, que "produziram histórias complexas de ocupação agrária, criação de territórios, cultural material e imaterial próprias baseadas no parentesco e no uso e manejo coletivo da terra" (GOMES, 2015, p. 7).

Esses territórios, então ocupados por pessoas escravizadas que conseguiam fugir, pertenciam a algum donatário e/ou sesmeiro, não contavam com titulações translativas de 
domínio ou de concessões de uso, caracterizando situações ilegais no âmbito jurídico. Nas palavras de Moura (1981, p. 29) "a economia agrícola desses redutos se organizava e se desenvolvia como um enclave à agricultura monocultora e latifundiária da Colônia escravista".

No entanto, a tensão entre senhor e pessoa escravizada não se esgotava no acesso à terra. Território e liberdade guardavam íntima vinculação. A antropóloga Ilka Leite explica: "mais do que uma exclusiva dependência da terra, o quilombo faz da terra a metáfora para pensar o grupo e não o contrário" (1999, p. 129).

Assim sendo, "Quilombos", "territórios", "territorialidade” são conceitos centrais para a compreensão da luta histórica do povo negro pela liberdade, uma afronta ao colonialismo que originou nas Américas, em geral, e no Brasil, em particular, o modo de produção escravocrata exportador. Logo, "quilombos eram sinônimos de transgressão à ordem escravista” (GOMES, 2015, p. 16).

Tárrega explica que, dentro desse sistema econômico: "o homem e a mulher escravizados foram convocados a reconfigurar suas vidas e a recriar modos de existência como resposta à própria continuidade do existir, e o fizeram a partir de uma integração com a natureza" (2019, p. 121). Desse lugar, decorre a centralidade do território quilombola como elemento de mobilização em defesa de suas liberdades.

Essa breve revisão histórica nos fornece fundamentos para a formulação da seguinte assertiva: a existência da comunidade quilombola Kalunga está intimamente interligada à colonização das Américas e porque houve intensa escravização no Brasil, o que provocou a diáspora forçada africana ${ }^{2}$.

No entanto, é mais especificamente na fase da economia escravista mineira do século XVIII, relacionada às vicissitudes da etapa de decadência da economia açucareira, que tem início o processo de ocupação das terras em Goiás e os primórdios da comunidade Kalunga. Assim, o processo de ocupação da Capitania de Goyaz, futuro Estado de Goiás, seguindo a tendência na América Latina e no Brasil, especificamente, se dá no intuito de extrair as riquezas naturais, dentro de um contexto de exploração predatória. E é dentro desse novo ciclo econômico que originam a composição e a trajetória do território Kalunga.

Em conversas com integrantes da comunidade quilombola Kalunga, de Cavalcante, Monte Alegre e Teresina de Goiás, percebe-se uma pluralidade de relatos na constituição e na trajetória da Comunidade.

\footnotetext{
${ }^{2}$ Schumaher e Brazil (2013) estimam cerca de quatro milhões de homens e mulheres "descarregados" dos porões dos navios negreiros no Brasil, vindos do continente Africano para exercerem múltiplas atividades e funções na construção de cada uma das regiões do País.
} 
Dalila Reis Martins, da comunidade quilombo Kalunga Engenho II, do Município de Cavalcante de Goiás, conta que ouviu de seus antepassados que a comunidade foi formada por negros e negras que eram escravizadas e fugiram de uma Fazenda chamada Mocambo, que hoje está situada na divisa entre os estados do Maranhão e Tocantins. Por outro lado, Manoel Eldetrudes Moreira, conhecido por "Tico do Kalunga", da comunidade quilombo Kalunga Núcleo "Faina", no Município de Monte Alegre, atribui a formação da comunidade Kalunga à Lei Áurea.

É normal que ocorra essa variedade de relatos, pois, como Moura (1981), Gorender (2016), Gomes (2015) e Fiabani (2005) apontam, os "quilombos" quase sempre se formavam a partir de pessoas escravizadas fugidas, mas não somente; portanto, não é de se estranhar que os relatos sobre a constituição e a trajetória da Comunidade Quilombola Kalunga sejam, por vezes, até divergentes, afinal, o grupo foi se espalhando por uma área de aproximadamente 261.999,6987 hectares, na atual divisa entre os estados de Goiás e Tocantins.

O que importa destacar, no entanto, é que a historiografia consensualmente aponta que os Kalungas se constituem no século XIX, ou seja, no auge do ciclo econômico aurífero na Capitania de Goyaz. E dentro dessa atividade econômica imperava uma mentalidade extremamente mercantilista que, durante algum tempo, identificou a riqueza com a posse de metais preciosos. Tendo em vista a importância econômica da mão de obra escravizada nessa atividade econômica, logo entendemos que os Kalungas representavam uma força social que transformavam um dos centros do sistema econômico aurífero, no Brasil escravocrata.

Dito de outra forma, as reações das Kalungas eram verdadeiros componentes de “desgaste econômico, social e psicológico do escravismo" (MOURA, 1981, p. 12). A averiguação desse fenômeno como recorrente, no espaço rural, rompe com o revisionismo historiográfico que visa atribuir às relações escravistas brasileiras uma moldura consensual, contratual, paternalista e benevolente (Cf. GOMES, 2015).

Vercilene Francisco Dias (2019, p. 58), com base nas histórias orais que ouvia ao longo de sua criação dentro da comunidade Kalunga, enfatiza que "a luta do povo Kalunga em defesa do território ocorre desde a sua formação". Percebemos, assim, que para os quilombolas a natureza não era considerada um meio hostil que precisava ser desbravada, mas uma aliada contra as "bandeiras desbravadoras".

E é assim que a Comunidade - na medida em que lutava por sua liberdade, lutava pelo território e contra a história do modelo fundiário e agrário colonial, lutava contra o colonialismo

\footnotetext{
${ }^{3}$ Sociedades de expedições com fins exploratórios territoriais e comerciais.
} 
português e seu modelo econômico imposto ao Brasil - resistiu ao tempo, protegida pelas barreiras naturais. Atualmente, localizada na região nordeste do Estado de Goiás, estendendose pelos municípios de Monte Alegre de Goiás, Teresina do Goiás e Cavalcante, dentro dessa circunscrição intermunicipal abrigam-se cinco núcleos, também chamados de "comunidades", sendo: Contenda, Kalunga, Vão de Almas, Vão do Muleque, Ribeirão dos Bois (antigo Ribeirão dos Negros). Ainda, esses cinco grandes núcleos se subdividem em vários outros agrupamentos com diversas denominações locais.

Constata-se que a comunidade quilombola Kalunga situa-se na região do Cerrado, a mais antiga das formações ambientais da história moderna do Planeta Terra, segundo o antropólogo e arqueólogo especialista no Cerrado, Altair Sales Barbosa, em entrevista ao documentário "Ser tão velho cerrado" (2018). O estudioso explica que trata-se de uma matriz ambiental localizada nos Chapadões Centrais do Brasil, onde existe a maior diversidade florística do mundo e grandes diversidades de animais do Planeta Terra, sendo importante para o equilíbrio dos biomas que o contornam ${ }^{4}$.

Dentro desse bioma, os Kalungas historicamente mantêm uma relação diferenciada com a terra. Não há, majoritariamente ${ }^{5}$, um perspectiva mercadológica em relação à terra e ao trabalho. As relações sociais, dentro da comunidade Kalunga, não são auxiliares do mercado, como descreve o teórico social Karl Polanyi em sua obra "A grande Transformação" (2000). Na comunidade, o trabalho e as demais as atividades estão inseridas nas relações sociais. Não é a economia que dita as relações sociais, mas as relações sociais que amoldam a economia.

Isto é, os Kalungas nutrem uma base econômica que não está desincrustada das relações sociais, inclusive, se reconhecendo como seres ecológicos, pois o vínculo com o território se equipara às relações parentais, as mulheres chegam a igualar o território Kalunga a um filho, a uma filha.

\footnotetext{
${ }^{4}$ Carla Guaitanele, ex-chefe do Parque Nacional da Chapada dos Veadeiros, em entrevista ao mesmo documentário, explica que o Cerrado é considerado um "hotspots", ou seja, área vista como de extrema importância por ter espécies que só se apresentam nele e que estão sob algum grau de ameaça.

5 "Majoritariamente" porque há contradições internas na comunidade. Existem Kalungas que se posicionam contrários ao título coletivo, desejosos de que o título fosse individual. Maria de Lourdes Bandeira (1990) aponta que isso se dá em decorrência de uma cultura jurídica, calcada na tradição legal europeia. A autora afirma que a invisibilidade jurídica do controle coletivo da terra, exercido costumeiramente pelas comunidades negras, tem se tornado um fator poderoso de dissolução dessas comunidades, na medida em que gera ambiguidade na consciência prática dos membros do grupo no contexto da sociedade de classes que conceitua a propriedade da terra como bem privado e, predominantemente, individual. Sobre essas contradições internas, conferir o trabalho: DIAS, Vercilene Francisco. Terra versus território: uma análise jurídica dos conflitos agrários internos na comunidade quilombola Kalunga de Goiás. 2019. 131 f. Dissertação (Mestrado) - Curso de Direito Agrário, Universidade Federal de Goiás, Goiânia, 2019. Disponível em: <https://repositorio.bc.ufg.br/tede/handle/tede/9607>. Acesso em: 29 nov. 2020.
} 
Assim, os Kalungas, povos formados no processo colonial a partir da escravização, mantêm uma organização social própria, diferenciando-se da sociedade hegemônica, que tem a sua forma de organização política no Estado-Nação.

\section{Comunidade Kalunga e a luta pela cidadania coletiva}

É a partir desse contexto sócio histórico e geopolítico, tratado acima, que quilombo vem a ser o mote principal para se discutir uma parte da cidadania negada para a população afro-brasileira, isso porque houve um silenciamento normativo de cem anos sobre essas comunidades no Brasil, desde a assinatura da Lei Áurea, em 1888.

$\mathrm{O}$ aperfeiçoamento legal referente às especificidades dessas comunidades de ancestralidade negra, bem como o ressurgimento do termo "quilombo" e sua ressignificação ${ }^{6}$, se dá a partir da Constituição Federal de 1988, devido à forte atuação e articulação dos movimentos negros, na fase anterior à Constituinte e durante a sua instalação (1987-88). Na Constituição, o Estado brasileiro afirma a garantia do direito à proteção das manifestações culturais afro-brasileiras, bem como o tombamento dos sítios históricos quilombolas (artigos 215 e 216). Ao empregar a expressão "antigos quilombos", há um ato de reconhecimento político-jurídico da existência dos quilombos, bem como a determinação de seu tombamento representa uma forma de restrição da propriedade privada onde se encontre o sítio histórico. Mas é no ADCT que a Constituição reconhece o direito à propriedade das terras de "comunidades remanescentes de quilombos", o que significa reconhecer os remanescentes como sujeitos constitucionais de direitos.

No entanto, previsão constitucional e supralegal não se desdobraram em concretização de direitos no campo institucional. O texto constitucional, legal, e mesmo uma decisão administrativa ou judicial não significam direito realizado, mas, tão somente, expectativa de direito, uma promessa. Nesse sentido, foi preciso uma articulação ampla e nacional - ou seja, a luta pelo "direito como efetividade", cuja realização e fruição se dão de forma concreta (Cf. SIQUEIRA, 2016).

\footnotetext{
${ }^{6}$ A definição jurídica de quilombos sempre enfatizou a ocupação coletiva e ilegal da terra. Um exemplo é a definição de "quilombo" e de "mocambo" dada pelo Conselho Ultramarino, em 2 de dezembro de 1740: "toda habitação de negros fugidos que passem de cinco, em parte despovoada, ainda que não tenham ranchos levantados nem se achem pilões neles". No entanto, posteriormente, "com o recrudescimento do escravismo, a Lei ${ }^{\circ} 236$, de 20 de agosto de 1847, sancionada pelo Presidente da Província Joaquim Franco de Sá, diminuiria o número de escravos fugidos, sem, contudo, imprimir singularidade ao conceito. Leia-se: Art. 12 - Reputa-se-ha [sic] escravo aquilombado, logo que esteja no interior das matas, vizinho ou distante de qualquer estabelecimento, em reunião de dois ou mais com casa ou rancho." (BRASIL. EMI N 58, 2003).
} 
Nesse sentido, em 1995, ocorre ato político sem precedentes para os movimentos negros brasileiros contemporâneos e para o movimento quilombola - a Marcha Zumbi Contra o Racismo, pela Igualdade e a Vida. Foi naquele momento histórico-político que ocorreu o $1^{\circ}$ Encontro Nacional de Comunidades Negras Rurais, entre os dias 17 a 20 de novembro (1995), tendo como lema: "Terra, Produção e Cidadania para os Quilombolas" (MEMORIAL DA DEMOCRACIA, 2020). A Marcha tem desdobramentos importantes, mostrando o alcance político dos movimentos negro e quilombola: primeiro, ao fazer reconhecer o racismo em evento oficial como elemento estruturante da sociedade brasileira ${ }^{7}$; segundo, porque o combate ao racismo entra na agenda política do País ${ }^{8}$.

Esse momento histórico está vivo na memória das lideranças Kalungas. Ao relatarem o processo de auto reconhecimento da Comunidade como Quilombola, Tico do Kalunga rememora como se deu:

Só que nóis chamava de comunidade Calunga né... toda vida comunidade Calunga, mas de Monte Alegre. O motivo de ser chamado "Kalunga", Teresina e Cavalcante, foi depois do estudo antropológico da Mari Baiocchi, aí a partir de 1982. Ela fez um estudo antropológico e devido ela conversar com várias comunidades, ela reconheceu que os mesmo sobrenomes que tinha no Município de Monte Alegre, "do Santo Rosa", tinha em Teresina e tinha em Cavalcante, "Fernando Castro", tinha de lá e tinha de cá, então ela reconheceu o vínculo de parentesco na comunidade. Então foi aí que ela registrou o laudo né... fez o tombamento e registrou como sítio histórico e patrimônio cultural os Kalungas dos três municípios. Então, a partir daí, passou a ser chamado Comunidade Quilombola né... que nóis nem sabia o que era quilombola. Mas quilombola foram as pessoa né... que formaram o quilombo no Brasil e mora em grupo né. Igual nóis aqui que mora em comunidade.

O senhor Tico do Kalunga continua recordando a Marcha Zumbi no processo de auto entendimento da comunidade como quilombola:

Nóis fizemo vários Encontro ... o primeiro Encontro Nacional foi em 1995, que nóis fizemo o Encontro da comemoração dos 300 ano de mortalidade do Zumbi de Palmares em Brasília. E ali, através daquele Encontro que nóis reconheceu a necessidade de criar a Coordenação Nacional de Quilombo do Brasil, que é a CONAQ.

\footnotetext{
${ }^{7}$ A Marcha Zumbi abriu caminho para que, em julho de 2016, fosse realizado o seminário internacional Multiculturalismo e racismo: o papel da ação afirmativa nos Estados democráticos contemporâneos, organizado pelo Ministério da Justiça, em 1996. O governo brasileiro, na pessoa do então Presidente da República Fernando Henrique Cardoso, inicia publicamente o processo de discussão das questões raciais brasileiras. Entende-se que essa conquista dos movimentos negro e quilombolas é um golpe para as teses de Gilberto Freyre, tecidas a partir de 1933, de um escravismo patriarcal, benigno e consensual no Brasil, que enseja o "mito da democracia racial". ${ }^{8}$ O Presidente Fernando Henrique Cardoso recebeu a marcha Zumbi e assinou o decreto que instituiu o Grupo de Trabalho Interministerial para a Valorização da População Negra. O movimento havia conseguido influenciar os rumos institucionais da luta contra o racismo no País.
} 
No mesmo sentido, recorda Ester Fernandes de Castro, representante da Associação do Quilombo Kalunga do Município de Teresina de Goiás:

Esse processo iniciou pelo Município de Monte Alegre, né. Pelo Município de Monte Alegre que iniciou essa luta pela questão da terra. E o reconhecimento veio em Teresina, né, iniciou em 1990 a luta pela terra. E o reconhecimento foi a partir duma Marcha em Brasília né, que foi em 1995. E por aí que veio essa questão do nosso reconhecimento. A gente foi em 1995 pra Marcha, a primeira Marcha de Zumbi. No final foi elaborado um documento né, pra reconhecimento das comunidades quilombolas.

Em síntese, é a partir da "Marcha Zumbi Contra o Racismo, pela Igualdade e a Vida", em 1995, que o debate sobre a identidade afro-brasileira ingressa na demanda nacional de reorganização fundiária. Vanderleia dos Santos Rosa, da comunidade quilombola Kalunga

Vão de Almas, no Município de Cavalcante, fala sobre o processo fastidioso de titulação da territorialidade Kalunga até a conquista do Decreto n. 4.887/2003:

O processo foi um processo de luta, árdua né. Como foi no relato do Tico, da Ester, né, que são uma das pessoa que tava aqui nesse evento hoje ${ }^{9}$, que presenciou toda essa luta né, de muito sofrimento, de muita angústia e expectativa, demora pra o título da terra né. E aí até que chega o Decreto que identifica e titulariza as terras quilombolas, né. E hoje a gente continua essa luta, o processo não termina, né ... ele é longo, ele é extenso, e ... hoje a gente tá no processo da concessão da cessão de direito de uso das terra né, que é na verdade, sendo entre a Associação Quilombo Kalunga, e muitas outra fazenda ainda pra ser indenizada.

Mas essa trajetória Kalunga de conquistas nos âmbitos estadual e nacional, e recentemente de retrocessos ${ }^{10}$, atuou, e continua atuando, como um processo contínuo educativo e de reidentificação, conforme explica Vanderleia dos Santos Rosa, da

\section{Comunidade Quilombola Kalunga Vão de Almas:}

Esse é um processo que ... eu acho lindo quando o representante da Associação não esquece nunca das pessoas que iniciaram a luta né. Porque talvez se não fosse eles - a dona Procópia, a dona Santina, o Sr. Santino, Sr. Florentino, até meu pai seguiu junto nessa luta né ... meu pai é o Faustino, na comunidade - não teria essa força aqui hoje que é dos mais jovens, que já estão ficando doutorando no assunto. Porque eu vejo a cada dia um enriquecimento maravilhoso, tanto no discurso... tem gente que é

\footnotetext{
${ }^{9}$ Referia-se a uma Assembleia que estava acontecendo na sede da Associação Quilombola Kalunga de Cavalcante, na qual finalizavam a elaboração do Regimento Interno da Comunidade, documento essencial para regulamentar as relações existentes dentro do território.

${ }^{10}$ Segundo a organização Terra de Direitos (2019), a Lei Orçamentária Anual (LOA) que define as diretrizes do orçamento público federal, sancionada pelo presidente Jair Bolsonaro, em meados de janeiro, indica que, para 2019, seriam disponibilizados apenas $\mathrm{R} \$ 3.423 .082,00$ para a titulação dos territórios quilombolas no País. Com isso, o valor destinado para a área caiu 93\%, após dez anos - em 2010, o orçamento chegou a $\mathrm{R} \$ 5,4$ milhões.
} 
graduado, tem gente que não tem nem o ensino fundamental e, no entanto, aprendeu tanto nesse decorrer, que assim, desde o início, o próprio Vilmar $^{11}$, a gente começou a luta junto, né, essa luta de retomada da Associação, né... de um grupo mais jovem, um grupo que tem uma visão diferenciada... começou comigo, Paulinho, Vilmar, todo mundo junto, não tem muito tempo, né. Eu lembro dos primeiros discursos, e aí eu olhando hoje, né, estão doutores. E como aprendem, indo pra faculdade ou não. Nessa luta, nesse movimento, o quanto as pessoas aprende. Eu fiquei encantada porque o discurso do Vilmar, no início não era esse, sabe? Não tinha essa qualidade. Do Tico, principalmente! Cê vê, o Tico é um companheiro que não tem nem o ensino fundamental, ele mal sabe assinar o nome, e quanto aprendizado né!

No entanto, o processo de se entender como quilombola é atravessado por conflitos e desconfianças, porque assumir a identidade quilombola é buscar sentido na existência da população afro-brasileira, para além da colonização e da escravização, ao mesmo tempo em que se tem conhecimento de que "a expressão quilombo vem sendo sistematicamente usada desde o período colonial" (LEITE, 1999, p. 127).

Ilka Boaventura Leite, tendo em vista o contexto colonial brasileiro, escreve que "quilombo" expressava uma vastidão de significados, o que representa uma grande quantidade de experiências. É importante destacar que esse termo, para se referir à população afrobrasileira, outrora pejorativo, passa a ser usado muito recentemente na historiografia brasileira. Conforme Leite (1999), o termo “quilombo", para se referir à identidade negra no período pósabolicionista, somente passa a ser usado, em fins da década de 1970, principalmente por Abdias Nascimento, Clóvis Moura e Décio Freitas; a partir daí, ganha espaço entre militantes negras e negros, chegando, em seguida, à formulação atualmente conhecida do artigo 68 do ADCT da Constituição Federal.

Dona Procópia dos Santos Rosa, da comunidade Kalunga do Riachão, Município de Monte Alegre, ao ser questionada sobre o processo de autoconhecimento da comunidade como quilombola, responde:

Dona Procópia: Não sei ... não sei como é que foi não... porque não explicou pra mim. Por que chama aqui de quilombola? não explicou ... eu tô aqui mas não sei de que lado que nóis veio, nem de que lado veio (risadas) ... Não sei não ... isso aí eu não sei não ...

Entrevistadora: E a senhora sabe o que significa ser quilombola?

Dona Procópia: Se nóis é?

\footnotetext{
${ }^{11}$ Presidente da Associação Quilombola Kalunga, chamada de "Associação mãe". Em 15 de novembro de 2020, foi eleito Prefeito do Município de Cavalcante, na região da Chapada dos Veadeiros, em Goiás; segundo a Coordenação Nacional de Articulação das Comunidades Negras Rurais Quilombolas (Conaq), é o único prefeito eleito quilombola do País.
} 
Entrevistadora: O que significa ser quilombola?

Dona Procópia: uai, minha filha, que foi escravo! Que foi escravo dos branco! É isso que é quilombola, num é?! Esse que foi escravo. Porque fazia isso. Porque de primeiro, diz que os preto num tinha liberdade, quem tinha liberdade era o branco. Disse que tinha os menino seco morrendo de fome ... que a gente já viu né, era tudo pretinho... é porque Deus ajudou que achou um governo que liberou os negro ${ }^{12}$, senão nóis tava tudo na peia ... tava até hoje, tava na peia...

As entrevistas coletadas convergem com o que explica a antropóloga Ilka Boaventura Leite, sobre o quanto é recente o debate da identidade quilombola e sua ressignificação, no contexto brasileiro:

É na década de 70 que tudo isto começa a mudar e "quilombo" passa a operar, como um novo signo na cultura, contribuindo para desestabilizar a ideia de país democrático, miscigenado, permissivo e mostrando um quadro onde a mulata é arrimo de família e o velho músico morre à mingua na mesa de um bar. Escolhido para falar da dominação que se tentou exercer através do argumento da inferioridade da raça, dos estigmas e da exclusão social, o termo quilombo vem expressar a necessidade de parte da sociedade brasileira de mudar o olhar sobre si própria, de reconhecer as diferenças que são produzidas como raciais ou étnicas (LEITE, 1999, p. 141).

Em suma, o caráter subversivo das ações e reidentificação étnico-racial Kalunga, principalmente das mulheres, como veremos mais à frente, juntamente com as pesquisas desenvolvidas por estudiosos envolvidos com a temática sobre comunidades negras rurais, do final dos anos de 1980 e início dos 1990, fez com que Goiás se tornasse o primeiro ente federativo brasileiro a pôr em prática o conteúdo disposto na Constituição brasileira, sobre tombamentos de documentos e sítios onde se encontrem reminiscências históricas dos antigos quilombos (artigo 216, § 5) (OLIVEIRA, 2007, p. 131).

\section{Mulheres Kalungas na luta pela efetivação dos direitos territoriais}

Gomes $(2015$, p. 39) chama a atenção para o fato de que "a demografia dos quilombos foi diversificada". Entende-se que essa diversidade é um dos elementos de compreensão da trajetória da comunidade Kalunga, que possibilitou ao quilombo atravessar os séculos XVIII,

\footnotetext{
${ }^{12}$ Percebe-se que, tanto dona Procópia, quanto o senhor "Tico do Kalunga" fazem menção positiva à Lei que aboliu a escravidão. Em que pese haver um repúdio contemporâneo desse fato histórico cristalizado na negação: "não houve abolição", a fala de ambos demonstra a necessidade de analisar fatos históricos na época em que ocorreram, bem como para o fenômeno de que não existe apenas um entendimento e significado sobre fatos históricos e seus desdobramentos e repercussões.
} 
XIX, XX, e chegar ao século XXI. No entanto, a historiografia especializada em quilombos economiza nos relatos sobre as mulheres, provocando um apagamento de suas atuações.

Há raras notícias sobre a presença da mulher nos mocambos, sugerindo equivocadamente sua ausência ou menor importância. Temos de lembrar que aqueles que descreveram os quilombos especialmente os comandantes de tropas - o faziam para justificar a necessidade de sua destruiçãa (GOMES, 2015, p. 39. Grifos nossos).

Em que pese esse apagamento historiográfico, os dados ilustram o fato de que as mulheres afro-brasileiras historicamente resistiram pelos seus territórios:

14.129.837 mulheres encontram-se no meio rural. O número de mulheres negras em meio rural é de 8.562.733, ou seja, o espaço rural brasileiro ocupado por mulheres é, em sua maioria, ocupado por mulheres negras (CONAQ; TERRA DE DIREITOS, 2018, p. 103).

Gomes (2015) afirma que os quilombos variavam quanto àqueles estáveis e improvisados, sendo que esses temporários eram formados majoritariamente por homens. $\mathrm{O}$ que nos leva a inferir, tendo em vista o tamanho da comunidade quilombola Kalunga, que a presença das mulheres fosse significativa: "nos quilombos maiores - mais estáveis e com uma população de segunda ou terceira geração - as mulheres podiam estar mais representadas demograficamente" (GOMES, 2015, p. 39).

Não se sabe em detalhes o cotidiano da comunidade quilombola Kalunga ao longo dos séculos, pois os relatos históricos são escassos. Tampouco, pretende-se, neste trabalho, idealizar a atuação das mulheres Kalungas, pois segue atento às críticas pós-coloniais contra a romantização dos sujeitos resistentes. O que se pretende, mediante a colheita de depoimentos sobre a atuação feminina, é lançar luz sobre um padrão de poder colonial que se mantém, de modo acentuado, no meio agrário brasileiro.

Segundo análise conduzida pela Oxfam Brasil (2016), a partir dos dados trazidos pelo Censo Agropecuário ainda de 2006, a manutenção da concentração da terra se mantém no Brasil, ocorrendo uma baixa mobilidade no perfil fundiário. Os reflexos dessa concentração vão além da maneira como a propriedade rural se distribui:

A desigualdade fundiária no Brasil também reforça a desigualdade de gênero. São os homens que controlam a maior parte dos estabelecimentos rurais e estão à frente dos imóveis com maior área: eles possuem $87,32 \%$ de todos os estabelecimentos, que representam $\mathbf{9 4 , 5 \%}$ de todas as áreas rurais brasileiras. No outro extremo, as mulheres representam quase o dobro do número de produtores rurais sem posse da terra em comparação aos homens - 8,1\% frente a 4,5\%, 
respectivamente. Ao mesmo tempo, as mulheres são, proporcionalmente, mais frequentes do que os homens nos estabelecimentos com áreas menores de 5 hectares (OXFAM BRASIL, 2016, p. 10. Grifo nosso).

Consequentemente, há uma escancarada relação entre o exercício do poder e a propriedade da terra, atrelada à questão de gênero, embora não seja um assunto muito tratado pelas "vozes autorizadas da sociedade". Portanto, trazer a experiência e trajetória feminina Kalunga como fio condutor para debater o processo de reconhecimento e titulação da comunidade quilombola, parafraseando o professor Sandro José da Silva (2009, p. 66), evidencia de que forma "a produção do direito trata de forma diferente aqueles grupos humanos segundo a demanda jurídica e política em questão", no presente caso, a demanda pela propriedade da terra desses novos sujeitos constitucionais de direitos.

A escolha metodológica de realizar entrevistas, dentro da comunidade Kalunga, teve a motivação de evidenciar as diferenças internas desses sujeitos históricos coletivos, as diferentes posições e visões sobre o auto reconhecimento como quilombo, bem como sobre a titulação coletiva em nome da Associação Quilombo Kalunga. Pois, como alerta Clóvis Moura:

\footnotetext{
Procurando-se, sempre, o enfoque chamado erudito, esquecem-se de que a apresentação de um esquema interpretativo sem a projeção das contradições estruturais da realidade significa cair-se em uma visão organicista em que tudo se ajusta porque essas contradições, nos seus diversos níveis, são descartadas para estabelecer-se a harmonia do modelo metodológico (MOURA, 1981, p. 7).
}

É uma verdade jurídica que o artigo 68, do ADCT da CRFB/88, reconhece as comunidades quilombolas como novos sujeitos constitucionais de direitos. No entanto, a colonialidade do poder e a colonialidade de gênero fazem com que as mulheres quilombolas se tornem "o outro" desses novos sujeitos constitucionais.

Assim, entender o lugar do gênero nas sociedades gera uma mudança no eixo de compreensão da importância e da sua magnitude na desintegração das relações comuns e igualitárias, bem como na desintegração dos processos coletivos de tomada de decisões e do modelo da economia. Neste ponto, convém explicar que o conceito de gênero usado neste trabalho "transcende o reducionismo biológico, interpretando as relações entre homens e mulheres como formulações culturais da imposição de significados sociais, culturais e psicológicos sobre desigualdades sexuais” (QUEIROZ, 2001, p. 125 e 126).

A importância de adotarmos uma lente de gênero, para analisarmos o processo de auto reconhecimento e titulação, se dá porque, no contexto da Comunidade Quilombola Kalunga, as mulheres quilombolas estão muito atreladas à família e à agricultura, como se percebe nos 
depoimentos colhidos. Nesse sentido, destacamos o depoimento de Natalina dos Santos Rosa, conhecida como Dona Dainda, da comunidade quilombola Kalunga Vão de Almas, situada no Município de Cavalcante:

Eu nasci lá na roça e fui criada, a gente não tinha muitos costumes, a gente vivia da roça, do que trabalhava, do que plantava. Eu fui criada assim ... minha mãe plantava algodão, fiava, tecia a coberta pra nóis. A gente custou muito para ter um costume. Meu costume até hoje é que eu não sei falar aquelas palavras bonitas, porque eu não estudei. Aprendi a assinar meu nome porque os outro não ensinava. Mas a gente viveu lá muito tempo, até hoje eu tenho meus oito filhos que moram lá. Três que moram em Goiânia, um em Brasília e os outros moram lá no Kalunga. Então, minha vida para criar esses filhos era trabalhando na roça: eu plantava roça, eu tinha minha própria casa, fazia minhas coisa de roça, fazia meu sabão, tirava óleo de coco, saia pra fora pra vender. E aí eu consegui criar meus oito filho e ainda dois neto, um neto e uma neta moram em Goiânia fazendo faculdade. E meu exemplo de conhecimento é só lá na roça. A gente vivia pescando, criava porco, galinha. $\mathbf{E}$ aí que foi minha sobrevivência até criar meus filho da natureza. Olha, pra falar pra você a verdade eu vim temperar com óleo de soja na minha casa eu já tinha três filhos. Em 1970 eu levei a primeira lata de óleo lá pra casa, eu temperava com banha de porco, óleo de coco que nóis mesmo tirava, óleo de gergelim, óleo de pequi. Minha vida foi uma vida muito difícil, mas graças a Deus, hoje agradeço a Deus, porque criei meus oito filho sem o pai ajudar. Os pais não ajudavam, foi eu mesma que criei meus filho, por isso que eu tive uma vida sofrida. Mas torno agradecer a Deus porque tive uma vida dependente de alimentação do que nóis tínhamo na roça: tinha muito arroz, feijão e nóis plantávamo muita coisa, e meus filho foi criado ... assim, conforme foi minha vida, meus filho foram bem melhores criado. A única coisa que na minha criação faltava era ter muita roupa. Não tinha, mas meus filho tiveram outra sorte. Os mais velho saíram pra trabalhar lá em Brasília e em Goiânia e me ajudava a criar os mais novo cá, que já teve outra oportunidade que de mim, que meus pais. Meu pai viajava muito, mas sabe era aquele pai que mais... era minha mãe que trabalhava na roça e cuidava dos filhos. Ele mexia com boiada e eu cheguei viajar um tempo com meu pai, quando ele saía pra comprar boiada e eu ia junto, mas eu vim ter uma vida melhor quando eu tinha 10 ano de idade, que minha mãe tinha uma máquina aí eu aprendi a costurar e eu fazia roupa pros outro, pra juntar meu dinheirinho e poder comprar alguma coisa, mas eu tive uma vida muito difícil na roça, assim, que trabalhava muito. Eu sei fazer cerca de arame, sei fazer muita coisa, eu mesma carregava as madeiras, colocava no lugar certo e abria os buracos e puxava o arame.

Percebe-se, em que pese a vida sofrida narrada por dona Dainda, que não havia dentro da comunidade uma repartição sexual do trabalho como o feminismo hegemônico costuma analisar, e que mesmo com todo sofrimento do trabalho físico, existe um forte sentimento de autonomia. A emancipação, para dona Dainda, está atrelada à possibilidade de manutenção física dos filhos (que ela atribui à natureza) e o acesso à educação formal. Angela Davis (2016, p. 109), tratando sobre educação e libertação na perspectiva das mulheres negras, afirma: "na 
realidade, a população negra sempre demonstrou uma impaciência feroz no que se refere à aquisição de educação. O anseio por conhecimento sempre existiu”.

Percebe-se, pela exposição de Dona Dainda, que as mulheres estão fortemente relacionadas à agricultura e à família; logo, esses elementos atuam como elemento-sujeito aglutinador em uma posse étnica e agroecológica que se organiza por vínculo de parentesco. Portanto, as mulheres são fundamentais para compreender o processo de auto reconhecimento da comunidade como quilombola. Dessa constatação, deriva a pergunta direcionada às entrevistadas: como foi e tem sido a atuação das mulheres no processo de reconhecimento da comunidade quilombola Kalunga?

Ester Fernandes de Castro, da comunidade Ema do quilombo Kalunga, representante da associação do quilombo Kalunga do Município de Teresina de Goiás, responde, destacando o protagonismo das mulheres na luta pelo território como "causa" da afirmação identitária:

Nós mulheres sempre estamos aí à frente na luta né. E iniciando lá por Monte Alegre, foi tia Procópia, tia Santina que hoje não é mais viva né. E em Teresina várias mulheres né que estão aí na luta, algumas não estão mais vivas também, que foi é ... que foi a tia Lió, Leonilda o nome dela, conhecida por tia Lió, que foi uma parteira né. E antes tinha mulheres lutadoras também, minha vó, Francelina, por exemplo, sempre foi uma mulher lutadora, uma líder na comunidade. Ela era parteira, rezadeira, né. Minha mãe também, né. Que era uma grande (pausa) ... Ela não era de tá assim nas reuniões, mas ela sempre tava ajudando na questão da luta, Ozilha Pereira. E outras mulheres: Efigênia, é ... Evangelista dos Santos Rosa, Maria dos Santos Rosa, é ... Irene... é ... Faria da Silva, que é falecida.

Entrevistadora: Eu ouvi que no começo, havia muito receio desse processo... que foram as mulheres que ...

Ester: É, no começo havia muito receio. Assim... muito por causa dos maridos né, que não gostavam que elas saíssem né, pra participar, mas depois, foi acabando mais esse... como diz assim ... esse machismo né. Os homens também foram vendo né, a importância das mulheres estarem. Que é as mulheres que ajudam. A maioria das mulheres é que ajuda na causa. E agora melhorou bastante né, as mulheres que estão na frente, maioria aqui é das mulheres que estão à frente.

Entrevistadora: Então, quer dizer que com a intenção de proteger o território os homens foram perdendo o machismo?

Ester: Eles foram amenizando. O território foi uma união.

Esse último trecho do relato analítico de Ester nos remete à antropóloga Leite e suas ponderações de como os territórios quilombolas, neste caso a Comunidade Kalunga, são uma metáfora do coletivo, um elo: 
A terra, evidentemente, é crucial para a continuidade do grupo, do destino dado ao modo coletivo de vida destas populações, mas não é o elemento de identificação principal. De todos os significados do quilombo, o mais recorrente é o que remete à ideia de nucleamento, de união, de associação solidária em relação a algo que está ou é considerado o que não é, o que está fora (LEITE, 1999, p. 136-237).

Eriene dos Santos Rosa, presidenta da Associação Kalunga de Cavalcante, atribui às mulheres mais velhas, principalmente na pessoa de dona Procópia dos Santos Rosa, o começo da demarcação do território. Para ela, o quadro atual, ainda que de poucos avanços, é apenas uma continuação das reivindicações daquelas mulheres:

Entrevistadora: Eriene, do que ouviu falar desse processo de auto reconhecimento como quilombola, qual foi o papel, a importância, das mulheres?

Eriene: Todo! Eu acho que a proponência, assim, em geral, foi sempre ... assim, tinha os homens, mas quem tava à frente eram sempre as mulheres, que era dona Lió, dona Procópia, tia Deuzelina, Ester! Tanto que o primeiro presidente que teve dentro da Associação Quilombo foi uma mulher, que foi tia Deuzelina. Primeira mulher que teve na Associação do Município, foi uma mulher também, que foi tia Deuzelina. Então eu acho assim, por mais que tinha Tico, tio Cirilo, Sr. Santo... quem tava sempre à frente, quem tava com a rédea ali mesmo era sempre as mulheres mesmo.

Dalila Reis Martins, da comunidade quilombo Kalunga Engenho II, Municípiode Cavalcante, explica que a atuação dessas mulheres não necessariamente teve impacto quantitativo; muitas vezes, uma quantidade pequena de mulheres tinha que abarcar uma gigantesca carga de atividades, o que explica, por exemplo, o nome de Deuzelina se repetir em mais de uma Associação, conforme contou Eriene dos Santos Rosa:

As mulheres, a maioria faziam na época o que seus maridos bem convinham. Só que tinham algumas mulheres que acreditavam na história do território ... no comecinho foram poucas, mas essas poucas faziam por muitas na batalha a favor do território. As mulheres tiveram papel, dona Procópia, aí depois veio tia Deuzelina, mas tinha outras mulheres que iam nas reuniões não importa de que forma. Minha mãe mesmo, ela ia nas reuniões como secretária, às vezes. Ela ia nas reuniões em Brasília, em Goiânia, como ouvinte. Ela ia participar pra fazer um quórum maior.

Vanderleia dos Santos Rosa, conhecida como "Vanda", da comunidade quilombola Kalunga, do núcleo Vão de Almas, recorda como cresceu vendo a atuação dessas poucas mulheres como um aprendizado, sendo que muitas não sabiam ler ou escrever:

Então ... eu vi assim ... crescendo ainda, eu vi a luta das mulheres do 
Município de Monte Alegre, dona Santina, dona Procópia; daqui do Diadema, mãe de Ester, dona Lió, né. É ... mulheres de destaque mesmo né, que foram à luta. E no início foram essas mulheres, né, que foram. E assim, a voz ativa era a voz de dona Procópia e dona Santina. Dona Santina já é falecida. E ela era esposa do meu tio Manoel, né, irmão da minha mãe. Então foi uma luta linda porque era de mulheres que não sabiam assinar nem o nome, mas elas tinham um poder de voz. Acho que posso dizer um poder de voz, de liderança, sabe? Que comovia as autoridades, comovia a comunidade. E eu acho que foi por isso que caminhamos até aqui. E é maravilhoso pensar isso, sabe.

Vanderleia dos Santos Rosa, também, fala da continuidade da luta dessas mulheres, através de suas netas, destacando a atuação das professoras Kalungas, graduandas e graduadas em licenciatura em Educação do Campo, - destacando o papel da Universidade Pública reivindicando a melhoria da educação dentro do território da Comunidade, e os conflitos ao formularem, junto à Secretaria de Educação, um currículo pedagógico próprio ao povo Kalunga.

Dona Procópia dos Santos Rosa, matriarca que todas as pessoas reconhecem a importância da sua liderança e a sua atuação, é a prova viva de que a ação de poucas mulheres proporcionou à comunidade quilombola Kalunga projeção internacional. Essa senhora de 86 anos, chamada por muitos de "tia Procópia" ou "iaiá Procópia", foi uma das mil mulheres (figurando entre 52 brasileiras) em todo o mundo, selecionada por um comitê internacional suíço, composto por organizações não governamentais e feministas e de direitos humanos, apresentada à Organização das Nações Unidas (ONU), para ganhar o Prêmio Nobel da Paz em 2005. Ela conta que, no começo, foi praticamente sua atuação e de dona Santina na reivindicação da regularização do território:

Entrevistadora: Queria que a senhora me contasse um pouco sua história, dona Procópia...

Dona Procópia: Cê quer que eu fale do meu trabalho? Do começo? Então ... como que eu vou explicar procê que ... meu projeto conseguiu com a dona Mari, né. A Mari que abriu as porta aqui ${ }^{13}$. E dela os outros foram vindo, foi Durval ${ }^{14} \ldots$ um bocado ... fui lá no governador, o governador

\footnotetext{
${ }^{13}$ Ela está se referindo à Mari Baiocchi, que a partir do projeto "Kalunga: Povo da Terra" (1981 - 2004), em parceria com a Universidade Federal de Goiás, conduziu os estudos antropológicos da Comunidade Kalunga, que mais tarde vão subsidiar a Lei Estadual n. 11.409, de 21 de janeiro de 1991, que constituiu patrimônio cultural e sítio de valor histórico a área de terras situadas nos vãos das Serras do Moleque, de Almas, da Contenda-Calunga e Córrego Ribeirão dos Bois, nos municípios de Cavalcante, Monte Alegre e Teresina de Goiás, no Estado de Goiás.

${ }^{14}$ Refere-se à Durval Mota, que presidiu o Instituto de Desenvolvimento Agrário de Goiás (Idago), durante o período de demarcação, em 1995, do Sítio Histórico e Patrimônio Cultural Kalunga, tombado pelo governo do Estado de Goiás em 1991. Algumas pessoas integrantes da Comunidade se referem a ele, afetuosamente, como "Kalunga branco".
} 
veio aqui... nosso primeiro colégio aqui foi o $\operatorname{Iris}^{15} \ldots$

Entrevistadora: Isso foi em que ano, a senhora lembra?

Dona Procópia: Lembro não, minha filha ... muitos ano ... foi no começo ... As primeira coisa que pedi praqui foi com o Santillo ${ }^{16}$, o primeiro governo dele... fui no Palácio dele duas vezes. Com o Santillo e o Iris, que eu fui lá no Palácio deles. E ... a inauguração do primeiro colégio aqui foi o Iris que inaugurou ... a mulher dele que veio entregar nossos cartão da terra, a Iris ${ }^{17} \ldots$ a Iris também conhece aqui, veio mais dona Mari. E por aí fui mais dona Mari [Mari Baiocchi] ... dona Mari fazendo pergunta, eu explicando as coisa como que era aqui... a dificuldade... (...) E aí todo ano mandava chamar aqui pra eu ir pra Goiânia, eu mais Santina. Nóis duas.

Entrevistadora: Quem que é Santina, dona Procópia?

Dona Procópia: Ela já morreu, já faleceu ${ }^{18}$. Era nóis duas que corremo atrás... nóis duas... mas era doente ... foi indo e morreu ... Aí, depois que ela morreu eu fui em São Paulo, já fui em Goiânia ... Fiquei sozinha... fiquei desentoada, minha filha... mas aí agora, até ano trasado me mandaram chamar em Goiânia, fui elogiada em Goiânia, ano trasado.

Entrevistadora: Pelo trabalho da senhora na comunidade?

Dona Procópia: Uai! Meu trabalho é pedir as coisa pra comunidade, né ... nóis tudo aqui não tinha nada ... não tinha estrada, o povo não tinha condição de nada ... só da roça... as muié não tinha contato com cidade ... era tudo só os homi que ia pra cidade, as muié não tinha condição de ir. Fazê? Não tinha dinheiro! Quando o homi arrumava um tiquinzim de dinheiro era só pra comprar o salzim [sal], comprar o café, o metro de pano pra vestir as muié. As muié onde é que tinha esse dinheiro? Não tinha nada! Naquele tempo, vei [velho] morria, aposentação de vei [velho] não tinha...

Entrevistadora: Qual foi o papel, a importância das mulheres nesse processo de auto reconhecimento como quilombo Kalunga, dona Procópia?

Dona Procópia: Não ... as muié ... elas ficou com medo. Depois que nóis foi andando, que nóis foi mais em Goiânia, foi andando, ficou rodando um pouco ainda aí, que elas foi conformando. Aí que todo mundo foi conformando, mas todo mundo tinha medo. O Vão de Almas todo mundo tinha medo ... Vixi! O povo tomou um medo de nóis aqui ... até povo do Canadá vei [veio] aqui! O Embaixador do Canadá tudo vei [veio] pra conhecer os Kalunga e ... e ... a primeira coisa que eles indicou pra vim pra nóis foi enxada, machado, foice, arame ... que o povo do Canadá deu pra comunidade. Veio aqui! A mulher do Canadá pretinha! o marido dela loiro dos zói verde ... (risos). Veio de helicóptero, sentou bem aí oh ...

\footnotetext{
${ }^{15}$ Refere-se ao então Governador de Goiás Iris Rezende Machado, no período de 1983 a 1986. Governou, também, no período de 1991 a 1994.

${ }^{16}$ Refere-se ao antecessor do segundo mandato de Iris Rezende no Governo de Goiás, Henrique Antônio Santillo, que governou de 1987 a 1990.

${ }^{17}$ Refere-se à dona Iris de Araújo, então primeira dama de Goiás, esposa do Governador Iris Rezende Machado.

${ }^{18}$ Refere-se a Santina Pereira Eldetrudes.
} 
Entrevistadora: Dona Procópia, então foi a senhora e a dona Santina que atuaram mais à frente desse processo de reconhecimento da área Kalunga como quilombo?

Dona Procópia: Foi ... nóis duas foi que corremo atrás. Mas pra falar lá, quem falava era só eu das muié ${ }^{19}$. Ela [Dona Santina] era minha acompanhante, ela foi presidente da Associação do Povo da Terra, a primeira Associação, ela foi presidente. E foi assinado em Campos Belo, Associação do Povo da Terra. Era ela que era presidenta. Quando mudou, completou, mudou, passou pra Associação Mãe, que é essa que tá com $\mathrm{ele}^{20}$. Agora esse do Povo da Terra, ganhou três caminhão, três caminhoneta, três casas. Cada comunidade um. Porque era da Terra, agora essa daí, essa Associação Kalunga só mesmo continuou. Mas as coisas que repartiram tudo foi da do Povo da Terra.

Fica evidente, na fala de dona Procópia, uma consideração muito grande pela atuação de Mari Baiocchi, que se iniciou por Monte Alegre de Goiás, porque o trabalho, para além das pesquisas da antropóloga, provocou significativa movimentação político-institucional por parte de autoridades do governo do Estado de Goiás, desde 1982²1. No entanto, há posições divergentes em relação à percepção da antropóloga sobre a comunidade Kalunga, é possível que, na ânsia de enquadrá-la dentro de uma visão metodológica - erudita, como diz Clóvis Moura (1981) - como "quilombo", a antropóloga tenha feito algumas afirmações organicistas, quando foram descartadas certas distinções dentro dos núcleos da comunidade Kalunga:

Os Kalungas remetem-nos à África, e o isolamento geográfico-cultural em que vivem ocasiona a reificação de suas tradições e costumes. Metodologicamente são vistos como descendentes de escravos que, à deriva da sociedade institucional, constroem uma cultura própria, tendo como parâmetro sua história de grupo "isolado" (BAIOCCHI, 2013, p. 18. Grifos nossos).

Essas notas de campo antropológicas causaram alguns incômodos, como se percebe na fala de Natalina dos Santos Rosa (dona Dainda), da comunidade Kalunga Vão de Almas, ao ser questionada sobre a atuação das mulheres no processo de reconhecimento do território como Kalunga:

Assim .... as mulheres, das mais velha... você fala quando foi reconhecido né? Assim ... as que mais começou foi tia Procópia, dona Santina, e foi reconhecendo mais mulhé... Mas quando essa mulher entrou lá, essa antropóloga, sei lá como é que diz, aí ela falou umas palavra lá fora que num era acontecido, porque ela falou que a gente comia sem sal, que as mulher não tinha calcinha. Não! Nessa época meu pai já viajava, meus avós

\footnotetext{
${ }^{19}$ Dona Procópia está explicando que dona Santina Pereira Eldetrudes sempre a acompanhava nas reuniões, mas que quem falava, nos espaços públicos institucionais, diante das autoridades políticas, era ela.

${ }^{20}$ Refere-se a Vilmar Souza Costa, atualmente presidente da Associação Quilombo Kalunga (AQK).

${ }^{21}$ Também, foi em 1982, a primeira vez que houve eleição de Governador de Estado, após o golpe civil-militar de 1964.
} 
já viajava! Quando eu era criança meus avó já iam comprar sal em Barreiras, na Bahia, no lombo do cavalo, que nem burro num tinha. Ia lá em Barreiras comprar sal! Cê tá entendendo isso? Outros pegavam o vapor, que hoje é Tocantins na Palma, e ia viajar de vapor até chegar né ... no Pará! Meus avós já conhecia o Pará, viajavam, iam um ano viajando pro Pará $^{22}$. Nóis num tava isolado, meu pai tinha 10 ano e saía pra viajar, saia pra trabalhar, porque as criança trabalhava muito nova. E ele trazia mercadoria de Barreiras, que era onde comprava sal e pano. E também meu pai trabalhava presses ricaços daqui de Cavalcante, donos de fazendas, ele ia em Goiânia, Anápolis, Catalão, comprar mercadoria pra eles. A gente já ... eu já sabia muito e num tava ninguém isolado mais não. Não! Nóis foi isso lá num sei em que $\mathrm{Era}^{23}$. Meus avós já sabiam viajar pra tudo quanto é lado, pra Barreiras, Goiânia, Anápolis, Catalão. Ele ia pra Goiânia comprar mercadoria pros donos de loja daqui de Cavalcante. E meu pai também chegou viajar pra São Paulo, pegava o trem em Goiânia e ia pra São Paulo. Meu pai não sabia ler, mas viajava até pra São Paulo pra trazer mercadoria de lá que era mais barato. Eu cheguei perguntar meu pai cumé que ele não sabia ler mas conhecia dinheiro e número das casa. Ele disse que quem sabia contar dinheiro sabia a numeração da casa. Desse jeito! E aí a gente viveu já muitos ano conhecendo, comprando mercadoria, só que na época não existia roupa pronta, comprava mercadoria lá e fazia as roupa. Eu mesmo fiz muita roupa, eu mesmo fazia. Não vendia, cada um comprava os panos e fazia, e quem não soubesse pagava quem sabia pra costurar.

A indignação de dona Dainda encontra respaldo em Clóvis Moura, que explica que os quilombos e quilombolas interagiram, ao longo de sua existência, tanto com grupos marginalizados da sociedade, quanto com segmentos econômicos e sociais que, "embora constitutivos da sociedade civil escravista, com eles mantinham relações, negócios, e muitas vezes, prestavam-lhes serviços" (1981, p. 28).

Para nos ajudar a entender essa situação, Carlo Ginzburg (1990) chama a atenção para a "procura da verdade" por parte de quem exerce a antropologia, que pode vir a produzir testemunhos extremamente ricos, mas distorcidos. Talvez, para usar um termo utilizado por Moura (1981), a comunidade Kalunga, com seus impasses e conflitos em seus núcleos, pode ser vista como uma "confederação de quilombos", na qual a vinculação do território se dá pelos laços parentais e não uma visão circular de uma unidade organicista, cadenciada, desses sujeitos coletivos. Logo, as mulheres, como mantenedoras dos núcleos familiares, são responsáveis por prolongar a vida desses quilombos no pós-abolição.

Vercilene Francisco Dias, Kalunga da Comunidade Vão do Moleque, no Município de Cavalcante, que comporta os núcleos Salinas, Congonhas, Prata, Morros, dentre outros,

\footnotetext{
${ }^{22}$ Sobre essa referência feita por dona Dainda, ver o Documentário "Rota do Sal Kalunga", que refaz a trajetória histórica do povo do Quilombo Kalunga, que precisava navegar de seu território, em Goiás, atravessando os atuais estados do Tocantins, Maranhão, até chegar em Belém do Pará, para trocar produtos, que produziam no Quilombo, por sal.

${ }^{23}$ Ela está dizendo: "nós fomos isso [isolados] não sei em que Era".
} 
afirma o protagonismo das mulheres no processo de luta para transformar uma promessa constitucional em direito como efetividade:

As mulheres Kalungas sempre exerceram papel importante na luta pela regularização e titulação do território, seja nas mobilizações, nas reuniões com entes do Estado, na política, seja na preservação do território, da cultura Kalunga nas festas e tradições.

Assim, identifica-se, ao longo da colheita das entrevistas, a importância de a historiografia trazer a trajetória e a perspectiva das mulheres Kalungas, pois os discursos engendrados a partir da modernidade tendem a invisibilizá-las. Um exemplo é a resposta dada pelo senhor Manoel Edeltrudes Moreira, Tico do Kalunga, ao ser questionado sobre a atuação das mulheres nesse processo de reconhecimento da comunidade como quilombo, bem como se havia alguma personalidade que ele considerasse emblemática nesse processo, a resposta foi: "aqui, na verdade, foi tudo misturado, homens e mulheres, né... criança" (MOREIRA, 2019). Entretanto, continua explicando o que houve, após a realização da Marcha Zumbi e a criação da Coordenação Nacional de Articulação das Comunidades Negras Rurais Quilombolas (CONAQ), em 1995:

(...) eu fui um dos coordenador [da CONAQ] de 2011, fui eleito no Rio de Janeiro, é... o ano passado né... Aí eu me afastei e agora têm outros colega, hoje aqui é o Damião que tá representando a CONAQ. Então eu hoje estou só como membro dessa organização (MOREIRA, 2019).

Importante reparar que o "Tico do Kalunga", como prefere ser chamado, expressa que a luta foi coletiva, envolveu todas as pessoas da comunidade, mas ao nomear as figuras que se destacaram na sua visão, nomeia tão somente os homens (ele próprio e Damião) e suas ações institucionais ou à frente das Associações, ou seja, os homens como protagonistas nos espaços públicos de atuação, de representação, de visibilidade.

\section{De como as mulheres e as comunidades coletivas são excluídas da modernidade}

Quando este trabalho aponta modernidade, o faz no sentido de marcação histórica e de racionalidade. José Geraldo de Souza Júnior apresenta três aspectos da modernidade:

(...) a modernidade compreendida como racionalidade científica e positiva que passou a rejeitar outras formas de conhecimento e de explicação da realidade, tais como as mítico-religiosas e as de natureza metafísica; a modernidade representada pela hegemonia da forma política do Estado, cuja expressão institucional passou a subordinar as 
experiências múltiplas de outros modos de organização política no espaço da sociedade; e a modernidade caracterizada pela supremacia do modo legislativo de realizar o Direito, isolando o jurídico na sua expressão formal (a codificação) por meio de uma colonização das práticas jurídicas plurais inscritas nas tradições corporativas e comunitárias (SOUSA JÚNIOR, 2008, p. 156. Grifo nosso).

No entanto, para chegar a esse momento histórico marcado pela racionalidade do pensamento e do conhecimento, houve uma transição. Rita Segato (2019) explica que, ao mesmo tempo em que se originou a organização colonial do mundo, abriu-se caminho para a modernidade. Por isso, a antropóloga, a partir das elaborações de Aníbal Quijano, aponta para a inter-relação "colonial-modernidade": "La precedencia del término colonial con relación al término modernidad indica la precondición necesaria del orden colonial para la existencia del orden moderno" (SEGATO, 2019, p. 72).

De acordo com a autora, na medida em que a organização do mundo abre caminho para a modernidade, as mulheres caem subitamente da posição que ocupavam no mundo comunitário. Segundo a antropóloga, não é que não houvesse hierarquia de gênero no mundo comunitário, a hierarquia existia, mas se dava principalmente na divisão sexual do trabalho e não tanto em hierarquias de poder: "existe una jerarquía de género y las tareas masculinas son investidas con un prestigio mayor" (SEGATO, 2019, p. 72). Entretanto, esse mundo comunitário, coletivo, era um mundo dual e coeso, pautado na reciprocidade. E mesmo com as hierarquias de gênero e o prestígio masculino, o espaço de atuação das mulheres por si era pleno e dotado de capacidade política própria.

A estudiosa argentina explica que na transição para a colonial-modernidade, a dualidade se torna binarismo, e binarismo implica no mundo "do um e seus outros". Então, o homem passa a ser universal e "normal" e a mulher passa a ser o outro do homem:

O trânsito para a colonial-modernidade é um processo pelo qual o espaço das tarefas masculinas passar a ser uma esfera englobante que sequestra tudo o que é dotado de capacidade política. O Estado e a esfera pública são então a última etapa da história dos homens, enquanto o espaço das mulheres ou o espaço doméstico é expropriado de toda capacidade política e se transforma na margem, no resto, um resíduo da política (SEGATO in REVISTA CULT, 2019, p. 29).

Mas, dentro da comunidade Kalunga, as atuações das mulheres são a materialização de uma capacidade política alternativa, quase extinta pela transição colonial-moderna. Nesse sentido, as entrevistadas foram questionadas: o que significava ser mulher Kalunga? Em resposta, Vanderleia dos Santos Rosa (Vanda), da comunidade Kalunga Vão de Almas, exalta a explosão da capacidade política feminina em sua manifestação: 
Eu penso que a mulher Kalunga é ser um símbolo de organização, né ... da família, da própria família, da base da família, né ... e são tantas coisas assim que vem, mas eu acho que pra resumir, é isso né, é ser a base familiar. E hoje as mulheres é a base não só da família, é de todo movimento. Cê vê que todos os espaços hoje, você pode contar, tem números significativos de mulher, nas escolas, em tudo quanto é lugar pode ver. A gente pode até ver a representação das Associações, que agora tá o Vilmar, mas a gente tem a Eriene, eu fui uns dois anos representante da Associação de Educação do Campo, do território Kalunga comunidades rurais, que é a Associação mais nova aqui do quilombo, que a gente construiu de 2009 pra cá, né, e que a Malu agora é representante. Então as mulheres não são somente a base da família, mas estão sendo também a base, o apoio, político, social, de todos os espaços na sociedade, né. A gente vê isso.

Vercilene Francisco Dias, da Comunidade Kalunga Vão do Moleque, respondeu que ser mulher Kalunga: "é ser resistente, que nunca descansa, estar presente para se fazer presente em uma sociedade que nos exclui por ser mulher, por ser negra, por ser quilombola".

E Dalila Reis Martins, da comunidade quilombo Kalunga Engenho II, do Município de

Cavalcante de Goiás, em sua resposta, traz a simbiose entre a mulher Kalunga e a natureza:

Olha ... já me perguntaram isso várias vezes. Eu nunca consigo responder a mesma coisa, porque cada etapa eu passo por provas diferentes. Ser mulher Kalunga é ser ... tipo a terra, a terra, ela nos dá tudo que plantarmos, a mulher Kalunga do mesmo jeito. Principalmente porque ela sofre um monte de depressão na vida dela na parte do amor, do carinho, do afeto. A mulher Kalunga, ela é super depressiva, né... mas mesmo com isso, ela sabe produzir amor pra quem não dá, carinho pra quem não dá, atenção pra quem a odeia, e sabe transformar em amor de novo. Então, a mulher quilombola Kalunga, se ela souber plantar amor, mesmo que a terra seja infértil... vai demorar, mas ela vai colher amor. Então, é isso que a gente trabalha na nossa terra... as verdadeiras quilombolas Kalungas, ela faz o ódio virar amor. É isso...

Eriene dos Santos Rosa, presidenta da Associação Kalunga de Cavalcante, traz na sua fala, sobre o que é ser mulher Kalunga, a necessidade de romper com uma visão binária moderna na qual a mulher é o outro do homem e a substitui pela consciência de que a mulher "tem que ser protagonista" da própria história:

Na minha visão pessoal? Eu tenho duas visões, eu tenho a minha visão antes da faculdade, a minha visão de comunidade, de mulher, de mãe, ali dentro, privada de várias coisas né. Que a gente acha que tá ali dentro da comunidade servindo o tempo todo - servindo que eu falo é marido e filho - já tá bom demais da conta né. Agora, quando a gente sai, que a gente estuda, que a gente conhece novos horizontes, a gente vê que pode ser protagonista da nossa própria história. Que a gente pode pegar outros viés, sabe? E que a gente é capaz, que a gente, que... tipo, nós somos referência, sabe? Que a partir da gente nossas filhas não vão deixar que os outros dominem elas o tempo todo, que elas sejam inferiores aos maridos, que na 
maior parte das comunidades é o que acontece, né. Então, acho que a gente que é mulher, a gente tem que ser primeiramente mãe, e a partir do momento de você ser mãe, por você ser mãe, você tem que ser mulher, tem que ser independente, tem que ser protagonista, porque é você que vai ser exemplo pras suas filhas.

Natalina dos Santos Rosa (dona Dainda), residente no Vão de Almas, na explicação do que representa ser mulher Kalunga, traz a dimensão da memória coletiva da comunidade:

Eu... pra mim... eu ser Kalunga... eu tenho um grande entusiasmo na minha vida deu olhar que eu sou uma Kalunga, e que eu acho que é uma pessoa que desde meus antepassados foi uma pessoa que lutou, que chegou até aí trabalhador, sobrevivendo. Eu, pra mim, é.... e eu fico sem comparação. E eu penso assim, são mulher de fibra, que num é só eu não! Todas kalungueira trabalha, sobrevive, cuida da vida, cria filhos sem o pai. E... pra mim... eu ser Kalunga é uma grande honra eu ser Kalunga. Eu pra mim é uma grande honra ser Kalunga... que eu me entendo de ser Kalunga é que é uma pessoa lutadora, trabalhadeira, tem nome, porque a única coisa que eu falo... a primeira coisa que eu falo é cê [você] ter seu nome.

\section{Ester Fernandes de Castro, da comunidade Ema do quilombo Kalunga,} representante da associação do quilombo Kalunga no Município de Teresina de Goiás, sobre ser mulher Kalunga remete à diáspora africana:

O ser Kalunga pra mim é representar as nossas origens africanas, né, que veio da África. E... estamos aqui no Brasil que viemos pra cá, que nossos antepassados vieram e trabalharam aqui né, sofridamente, e nós tamos aqui resistindo pra ter nossos direitos garantidos. Ser mulher Kalunga é... é tudo ... é... como se diz é um orgulho né, de ser mulher Kalunga. Por ter nascido, ter resistido e ter a força que veio dos nossos antepassados. É isso que eu digo.

Quando foi questionado à dona Procópia dos Santos Rosa, da comunidade Kalunga Riachão, o que é ser mulher Kalunga, ela respondeu: "Uai... e eu sei lá o quê que é uma mulher Kalunga! Porque é o lugar que chama Kalunga aí...”. Nesse momento, a neta de dona Procópia (Lurdes Fernandes de Souza) interferiu na entrevista, se dirigiu à avó e disse: "fala: ser mulher Kalunga é ser Procópia!" Dona Procópia soltou uma gargalhada com a orientação da neta e em seguida disse: "eu sei de nada não, minha filha!". Logo após, foi perguntado à dona Procópia o que era positivo e o que podia ser considerado negativo ao assumirem a identidade "quilombola", e ela, de pronto, respondeu:

Não... eu não sinto nada negativo é tudo positivo, porque Deus deixou nóis pra ser isso, é pra ser isso. Por que como é que nóis há de mudar? Já foi dirigido por Deus, né? Porque tudo é por Deus e cada um tem uma situação, não é? E aí, quê que nóis vai desmanchar? Não! O que saiu pra nóis, pra mim tá é bão. 
Essa explicação, que erroneamente pode sugerir um conformismo existencial de Dona Procópia, passa longe de refletir o seu próprio ativismo na construção de um sujeito individual e coletivo de direitos, como reconhecido, acima, por ela mesma e, marcadamente, nas manifestações de outras mulheres como Vanderleia dos Santos Rosa, Ester Fernandes de Castro, Eriene dos Santos Rosa e Natalina dos Santos Rosa (dona Dainda).

Transcritas essas falas, nota-se que "a perspectiva de luta das mulheres quilombolas é sempre uma luta coletiva. $\mathrm{O}$ ativismo por direitos para as mulheres quilombolas passa pela luta por direitos de toda a comunidade" (CONAQ, 2018). Isto é, na medida em que há uma simbiose entre terra e mulheres, defender o território Kalunga é proteger uma extensão do corpo das mulheres Kalungas, tal qual proteger e defender os direitos à terra coletiva representa proteger e defender a terra de seus ancestrais e de sua descendência (filhas/os, netas/os e bisnetas/os).

Nas entrevistas expostas ao longo deste trabalho, pode-se observar que, na comunidade quilombola Kalunga, as mulheres detêm o papel de manutenção da família. Se o quilombo se organiza a partir da posse agroecológica (familiar/parentesco), elas têm importância fundamental para a existência e manutenção da comunidade, bem como na sua organização interna e na expressão de suas lutas externas.

E essa deliberação feminina, no espaço doméstico, tem um impacto, uma influência na vida coletiva, na vida pública da comunidade. Aqui, conforme aponta Segato (2019), doméstico não é sinônimo de privado e tampouco é igual a íntimo. Essas equivalências são próprias da modernidade. Em outras palavras, a mulher Kalunga tem poder aglutinador dentro dessa forma de posse agrária.

Dessa forma, percebe-se que há uma reação das mulheres Kalungas contra as barreiras impostas pela intervenção colonial. Há, inclusive, um reconhecimento das mulheres mais novas da fundamental atuação das mais velhas, sempre recordando dona Procópia, dona Santina, dona Dainda, dentre outras precursoras, em suas falas.

Entretanto, das falas, também, se consolida o que Segato (2019) explica sobre as duas faces da modernidade: na medida em que as mulheres têm uma queda abrupta da posição que tinham no mundo comunitário, a luta por direitos vem compensar essa mudança. Por isso, a autora sustenta que a modernidade oferece com uma mão o que retirou com a outra.

\section{Conclusões}


Constatamos que a historiografia promove um apagamento da atuação das mulheres nas trajetórias dos quilombos no Brasil, em geral, e na comunidade Kalunga não foi diferente. No entanto, as entrevistas realizadas evidenciaram que principalmente as mulheres Kalungas, com seus protagonismos, movimentam consideravelmente a economia do território, que sustentam a casa, a família e, portanto, o vínculo na comunidade, que se estende por três municípios goianos.

Em síntese, as entrevistas realizadas demonstram que as experiências das mulheres Kalungas evidenciam uma inadequação ao feminismo dominante. Suas experiências e discursos revelam as realidades históricas, políticas, sociais e emocionais da constituição da comunidade quilombola Kalunga e das respostas às suas reivindicações às instituições do Estado, a partir da sua constituição como sujeitos de direitos. Por isso, essas experiências e discursos merecem ser articulados, teórica e metodologicamente. A atuação dessas mulheres retrata a complexidade dos processos sociais, políticos, econômicos e jurídicos nos quais as sociedades tradicionais estão inseridas.

Pode ser verificado que a "propriedade moderna" reforça a desigualdade de gênero e, também, a desigualdade étnico-racial, uma vez que os homens continuam controlando a maior parte dos estabelecimentos rurais no Brasil. Dentro dessa realidade agrária, o direito à vida é um direito básico fundamental, sendo que para a comunidade Kalunga ele se desdobra em dois outros direitos: o de ser (identidade histórica) e o de estar em sua territorialidade (reconhecimento da propriedade quilombola). O direito de ser enquanto grupo, com sua forma própria de organização, suas autonomias decisórias; e o direito à titulação definitiva da terra que é a sua territorialidade e não "propriedade-mercadoria".

A partir das entrevistas, o presente artigo registra que as lutas decoloniais pela sobrevivência são cotidianamente travadas nas gretas e gritos dos processos de reexistências coletivas das mulheres Kalungas, tendo sido elas pioneiras e protagonistas ao confrontar a perspectiva da propriedade clássica no Estado de Goiás, focando no aspecto do uso coletivo do povo Kalunga.

Por fim, notou-se que a comunidade Kalunga inverte a compreensão civilista do "proprietário que detém a coisa", uma vez que a identidade da comunidade e das pessoas Kalungas nasce pertencendo à uma terra, e não a terra que os pertence, por isso, a terra como metáfora para o grupo, como se confirma nas palavras das Mulheres protagonistas Kalungas.

\section{Referências}


A LADAINHA DA DEMOCRACIA RACIAL. Intérpretes: Lilia Schwarcz. São Paulo, 2018. P\&B. Disponível em: $<$ https://www.youtube.com/watch?v=KIZErDa1jIc $>$. Acesso em: 08 jan. 2018.

AGÊNCIA BRASIL (Brasil). Brasil tem 52 indicadas a Nobel da Paz coletivo. 2005.

Disponível em: <http://memoria.ebc.com.br/agenciabrasil/noticia/2005-06-29/brasil-tem-52indicadas-nobel-da-paz-coletivo $>$. Acesso em: 29 out. 2019.

BAIOCCHI, Mari Nasaré. Kalunga: Povo da Terra. Goiânia: UFG, 2013. 132 p.

BANDEIRA, Maria de Lourdes. Terras Negras: invisibilidade expropriadora. Textos e Debates Terras e Territórios de Negros no Brasil, Florianópolis, v. 2, p. 7-23, 1990.

BRASIL (Estado). Constituição (1988). Constituição Federal, de 05 de outubro de 1988. Brasília, DF, 05 out. 1988. Disponível em:

http://www.planalto.gov.br/ccivil_03/constituicao/constituicao.htm. Acesso em: 29 out. 2020.

BRASIL. Presidência da República Casa Civil Subchefia Para Assuntos Jurídicos. Poder Executivo. EMI N. 58. 2003. Disponível em:

$<$ http://www.planalto.gov.br/ccivil_03/Exm/2003/EMI58-CCV-MINC-MDA-SEPPIR03.htm>. Acesso em: 27 nov. 2019.

CONAQ; TERRA DE DIREITOS. Racismo e Violência contra quilombos no Brasil. Curitiba: Terra de Direitos, 2018.

DAVIS, Angela. Mulheres, raça e classe. São Paulo: Boitempo, 2016. 244 p.

DIAS, Vercilene Francisco. Terra versus território: uma análise jurídica dos conflitos agrários internos na comunidade quilombola Kalunga de Goiás. 2019. 131 f. Dissertação (Mestrado) - Curso de Direito Agrário, Universidade Federal de Goiás, Goiânia, 2019. Disponível em: <https://repositorio.bc.ufg.br/tede/handle/tede/9607>. Acesso em: 03 set. 2019.

FIABANI, Adelmir. Mato, Palhoça e Pilão: O quilombo, da escravidão às comunidades remanescentes [1532-2004]. São Paulo: Expressão Popular, 2005. 424 p.

GINZBURG, Carlo. O inquisidor como antropólogo. São Paulo: Rev. Bras. de Hist., v. 1, n. 21, 25 fev. 1990.

GOMES, Flávio dos Santos. Mocambos e Quilombos. 2015: Claro Enigma, 2015. 235 p.

GORENDER, Jacob. A escravidão Reabilitada. São Paulo: Expressão Popular, 2016. 296 p. LEITE, Ilka Boaventura. Quilombos e quilombolas: cidadania ou folclorização? Horizontes Antropológicos, [s.1.], v. 5, n. 10, p.123-149, maio 1999. FapUNIFESP (SciELO). http://dx.doi.org/10.1590/s0104-71831999000100006.

MEMORIAL DA DEMOCRACIA (Brasil). Instituto Lula. Marcha Zumbi reúne 30 mil em Brasília. Disponível em: $<$ http://memorialdademocracia.com.br/card/marcha-zumbi-reune30-mil-em-brasilia>. Acesso em: 02 jan. 2020. 
MOURA, Clóvis. Os quilombos e a rebelião negra. São Paulo: Brasiliense, 1981. 100 p.

MUNIZ, Izadora Nogueira dos Santos. A face feminina Kalunga frente ao modelo de desenvolvimento nacional: a condução do licenciamento ambiental da PCH Santa Mônica no sítio histórico da comunidade quilombola Kalunga. 2020. 157 f. Dissertação (Mestrado) Curso de Direito Agrário, Faculdade de Direito, Universidade Federal de Goiás, Goiânia, 2020. Disponível em: https://repositorio.bc.ufg.br/tede/handle/tede/10391. Acesso em: 29 out. 2020.

OLIVEIRA, Rosy de. O barulho da terra: Nem Kalunga nem camponeses. 2007. $230 \mathrm{f}$. Tese (Doutorado) - Curso de Sociologia e Antropologia, Universidade Federal do Rio de Janeiro, Rio de Janeiro, 2007. Cap. 5. Disponível em:

$<$ https://odonto.ufg.br/up/133/o/rosy.pdf>. Acesso em: 27 nov. 2019.

OXFAM BRASIL. Terrenos da Desigualdade: Terra, agricultura e desigualdade no Brasil rural. São Paulo: Oxfam, 2016. 32 p. Disponível em: <https://oxfam.org.br/projetos/terrenosda-desigualdade-terra-agricultura-e-desigualdade-no-brasil-rural/>. Acesso em: 26 set. 2019.

POLANYI, Karl. A grande transformação: As origens da nossa época. Rio de Janeiro: Editora Campus, 2000. 337 p.

QUIJANO, Aníbal. Colonialidade do poder, Eurocentrismo e América Latina. 2005. Disponível em: $<$ http://biblioteca.clacso.edu.ar/clacso/sursur/20100624103322/12_Quijano.pdf>. Acesso em: 03 set. 2019.

Revista Cult. Entrevista com Silvia Federici. Escravos e Bruxa. São Paulo, v. 217, 2016.

SCHUMAHER, Schuma; BRAZIL, Érico Vital. Mulheres negras do Brasil. Ed. condensada. Rio de Janeiro: Senac Nacional, 2013.

SEGATO, Rita. El tránsito a la modernidad implicó un desplome de la autonomía, de la autoridad y del poder de las mujeres. In: SEGATO, Rita; EQEIQ, Amal; DAYANHERZBRUN, Sonia. Feminismos a la contra: Entre-vistas al Sur Global. América Latina: La Vorágine, 2019. p. 71-88. Disponível em: <https://lavoragine.net/wpcontent/uploads/2019/07/Feminismos-a-la-contra.pdf>. Acesso em: 14 dez. 2019.

SER tão velho Cerrado. Direção de André D'elia. 2018. P\&B.

SILVA, Sandro José da. Verdades que se produzem: os territórios quilombolas e o direito no estado do Espírito Santo. Revista Videre, [S.1.], v. 1, n. 2, p. 65-84, maio 2010. ISSN 2177 7837. Disponível em: <https://ojs.ufgd.edu.br/index.php/videre/article/view/692>. Acesso em: 01 nov. 2020.

SIQUEIRA, José do Carmo Alves. Direito como Efetividade: a luta pela terra no Brasil. 2016. 363 f. Tese (Doutorado) - Curso de Doutorado em Direito, Faculdade de Direito, Universidade de Brasília, Brasília, 2016. Cap. 4. Disponível em:

$<$ https://repositorio.unb.br/bitstream/10482/20490/1/2016_Jos\%C3\%A9doCarmoAlvesSiquei ra.pdf>. Acesso em: 02 jan. 2020. 
SOUSA JÚNIOR, José Geraldo de. Direito como liberdade: o direito achado na rua experiências populares emancipatórias de criação do direito. 2008. 338 f. Tese (Doutorado) Curso de Doutorado em Direito, Faculdade de Direito, Universidade de Brasília, Brasília, 2008. Cap. 8.

SOUZA FILHO, Carlos Frederico Marés de; PRIOSTE, Fernando. Quilombos no Brasil e direitos socioambientais na América Latina. Revista Direito e Práxis, [s.1.], v. 8, n. 4, p.2903-2926, dez. 2017. FapUNIFESP (SciELO). http://dx.doi.org/10.1590/2179$8966 / 2017 / 31219$.

TÁRREGA, Maria Cristina Vidotte Blanco. (2019). Direito, devir negro e conflito ecológico distributivo. Revista Da Faculdade De Direito da UFG, 42(2), 120-140. https://doi.org/10.5216/rfd.v42i2.56534.

TERRA DE DIREITOS (Curitiba). No atual ritmo, Brasil levará mil anos para titular todas as comunidades quilombolas. 2019. Disponível em:

$<$ https://terradedireitos.org.br/noticias/noticias/no-atual-ritmo-brasil-levara-mil-anos-paratitular-todas-as-comunidades-quilombolas/23023 >. Acesso em: 28 jul. 2019.

Data de recebimento: 02.03.2021

Data de aprovação: 04.04.2021 